\title{
Heterologous Expression and Purification of a Heat-Tolerant Staphylococcus xylosus Lipase
}

\author{
Fábio Cristiano Angonesi Brod • Márcia Regina Pelisser • \\ Jean Borges Bertoldo · Javier Vernal · Carlos Bloch $\mathbf{~ J r} \cdot$ \\ Hernán Terenzi · Ana Carolina Maisonnave Arisi
}

Published online: 31 October 2009

(C) Humana Press 2009

\begin{abstract}
Staphylococcus xylosus is a microorganism involved in fermentation of meat products and also a natural producer of extracellular lipases. The aim of the present work was to clone and express in E. coli a lipase from S. xylosus (AF208229). This lipase gene (1084 bp) was amplified from a S. xylosus strain isolated from naturally fermented salami and introduced in pET14b expression vector in order to express the recombinant fusion protein (histidine-tagged lipase) in E. coli. Recombinant histidine-tagged S. xylosus lipase was purified by affinity chromatography in an HPLC system. The histidine-tagged lipase is a monomer in solution, as determined by size-exclusion chromatography. It presents a high lipase activity at $\mathrm{pH} 9.0$ and $42^{\circ} \mathrm{C}$ for $p$-nitrophenyl acetate and $p$-nitrophenyl butyrate, among seven different esters assayed $\left(\mathrm{pNPC}_{2}, \mathrm{pNPC}_{4}, \mathrm{pNPC}_{10}, \mathrm{pNPC}_{12}, \mathrm{pNPC}_{14}\right.$, $\left.\mathrm{pNPC}_{16}, \mathrm{pNPC}_{18}\right)$. Moreover, the enzyme presented a quite interesting thermal stability, after an incubation
\end{abstract}

Electronic supplementary material The online version of this article (doi:10.1007/s12033-009-9218-0) contains supplementary material, which is available to authorized users.

F. C. A. Brod · M. R. Pelisser · A. C. M. Arisi ( $\square)$

Depto de Ciência e Tecnologia de Alimentos, Universidade

Federal de Santa Catarina, Rod. Admar Gonzaga, 1346,

Florianopolis, SC 88034-001, Brazil

e-mail: arisi@cca.ufsc.br

J. B. Bertoldo $\cdot$ J. Vernal $\cdot$ H. Terenzi

Centro de Biologia Molecular Estrutural, Depto de Bioquímica,

Universidade Federal de Santa Catarina, Florianopolis,

SC 88040-900, Brazil

C. Bloch Jr

Laboratório de Espectrometria de Massa, EMBRAPA, Recursos

Genéticos e Biotecnologia, Brasilia, DF, Brazil period of $10 \mathrm{~min}$ at $95^{\circ} \mathrm{C}, 77 \%$ of the initial activity was retained.

Keywords Staphylococcus xylosus $\cdot$ Lipase $\cdot$ E. coli expression

\section{Introduction}

Lipases (triacylglycerol acylhydrolases, EC 3.1.1.3) catalyze the hydrolysis and synthesis of esters formed from glycerol and fatty acids, being the enzymes with the broadest use in biocatalysis [1]. Despite widely spread in several species, microbial lipases have more industrial potential and are often more useful than enzymes from other sources due to their substrate specificity and ability to remain active in organic solvents, high yields, and ease of genetic manipulation [2]. Moreover, bacterial lipases are preferential enzymes for a wide range of industrial reactions due to its catalytic activity in aqueous and non-aqueous reactions [3]. Lipases act at lipid-water interface and their catalytic activity results from the aminoacid residues triad containing serine, usually occurring in the consensus sequence Gly-X-Ser-X-Gly, Asp/Glu and His. Analyzing the three-dimensional structures of lipases, the presence of a typical $\alpha / \beta$-hydrolase fold was observed $[4,5]$.

Although lipase activity can be defined as the ability to hydrolyze triglycerides, lipases also can catalyze other reactions such as esterification or interesterification. A particular interest relies on lipases capacity of catalyzing such reactions and, consequently, the synthesis of fine compounds used for manufacturing products of high aggregate value, such as trans-free structured lipids [3, 6-8]. Each application requires unique properties with respect to specificity, stability, temperature, and $\mathrm{pH}$-dependence [9]. 
In order to use lipases for hydrolysis, esterification, or other applications, it is essential to produce the purified enzyme at high concentrations and to characterize biochemically this enzyme. Only about $2 \%$ of world's microorganisms have been tested as enzyme sources until 2006, and lipases from different sources have large variations in enzymatic activity, fatty acid specificity, optimal temperature, and $\mathrm{pH}$ [2]. More recently several new lipases have been characterized [10-14].

Staphylococcus xylosus is a coagulase negative Staphylococcus species that is commonly isolated from fermented meat products [15-19]. In these products, Staphylococcus ssp are responsible for color stabilization, decomposition of peroxides, and aroma formation due to its proteolytic and lipolytic activities [20, 21]. Rosenstein and Götz [6] determined the sequence of nine lipase genes from six Staphylococcus species including S. xylosus lipase AF208229. All lipases are similarly organized as pre-proproteins with pre-regions corresponding to a signal-peptide of 35-38 amino acids, a pro-peptide with hydrophilic characteristics composed of 207-321 amino acids, and a mature peptide containing 383-396 amino acids. Lipases are secreted as pro-proteins, being processed to mature form by specific proteases.

The lipase AF701336 from S. xylosus isolated from waste of an oil industry was purified and characterized [22]. Rosenstein and Götz [6] have published the sequence of gehM gene corresponding to the lipase AF208229 from S. xylosus (DSM 20266 strain); however, this lipase has never been overexpressed or characterized. S. xylosus lipase gehM expression was studied and it was suggested that an increase in triglycerides content in the growth medium suppresses the expression of this lipase gene [16]. The aim of the present work was to clone, overexpress, purify, and characterize a lipase from Staphylococcus xylosus isolated from naturally fermented sausages.

\section{Materials and Methods}

Bacterial Strains, Plasmids, and Chemicals

E. coli strain DH5 $\alpha$ was used as a host for gene cloning and plasmid propagation, and strain BL21 (DE3) pLysS for protein expression. Plasmid pGEM-T Easy Vector (Promega) was used for sub-cloning and sequencing of the lipase gene, while pET-14b (Novagen) was used as expression vector. Restriction enzymes were purchased from Promega and the HiTrap affinity column from GE Healthcare. The $p$-nitrophenyl esters and isopropyl-L-thio$\beta$-D-galactopyranoside (IPTG) were purchased from Sigma. S. xylosus strain was isolated from naturally fermented sausages [23].
PCR Amplification, Cloning, and Sequencing of Lipase Gene

A fragment coding to the mature lipase AF208229 from S. xylosus strain was amplified by PCR using primers LIP1 (5'-GCTGCAAAACAAGGACAGTATAA- $\left.3^{\prime}\right)$ and LIP2 (5'-TAAGCATCAAATTGCTCGTTACGA- ${ }^{\prime}$ ). Amplification reactions were performed in a final volume of $25 \mu \mathrm{l}$ containing $1 \times$ PCR buffer $(20 \mathrm{mM}$ Tris-HCl, pH 8.4 , $50 \mathrm{mM} \mathrm{KCl}), 2 \mathrm{mM} \mathrm{MgCl}_{2}, 0.2 \mathrm{mM}$ of each dNTP, $0.5 \mathrm{mM}$ of each primer, $1 \mathrm{U}$ of Taq DNA polymerase, and $50 \mathrm{ng}$ of template DNA. Amplifications were carried out in a Minicycler $^{\mathrm{TM}}$ (MJ Research Inc., Watertown, MA) with the following program: denaturation at $95^{\circ} \mathrm{C}$ for $5 \mathrm{~min}$; followed by 40 cycles of $95^{\circ} \mathrm{C}$ for $1 \mathrm{~min}, 50^{\circ} \mathrm{C}$ for $1 \mathrm{~min}$, and $72^{\circ} \mathrm{C}$ for $1.5 \mathrm{~min}$; final extension at $72^{\circ} \mathrm{C}$ for $7 \mathrm{~min}$.

The PCR product was re-amplified using primers LIPET 1 (5'-TTCTCGAGCAAGGACAGTATAAAAAC C-3') and LIPET2 (5'-TTACGGATCCTCAGTAGGATG ATT- $3^{\prime}$ ). Resulting fragment was purified with Concert Rapid PCR kit (Gibco BRL) and inserted into pGEM-T Easy vector (PROMEGA). This plasmid, $p G E M \_l i p 2$, was used for transformation of $E$. coli DH5 $\alpha$.

Assembly and analysis of DNA sequences were performed in a MegaBace1000 (Amersham Biosciences, Piscataway) at the Centro de Biotecnologia, Universidade Federal do Rio Grande do Sul, Brazil. BLAST was used for database searches. Comparison of the cloned lipase gene with lipase gene AF208229 was carried out using ClustalX (version 2.0.9) software.

\section{Construction of pET14b_lip Expression Vector}

DNA fragment obtained from digestion of $p G E M \_l i p 2$ vector with XhoI/SalI was ligated in frame into pET14b vector previously digested with $\mathrm{XhoI}$ and dephosphorylated. The insertion of the mature lipase gene was confirmed by restriction analysis with EcoRI enzyme. Recombinant plasmid was named $p E T 14 b \_l i p$. Expressed protein carries $\mathrm{N}$-terminal $\mathrm{His}_{6}$-tag encoded by the expression vector.

Expression and Purification of Lipase

pET14b_lip was used to transform E. coli BL21 (DE3) pLysS strain. Cells harboring the $p E T 14 b \_l i p$ plasmid were inoculated in $10 \mathrm{ml} \mathrm{LB}$ broth supplemented with $100 \mu \mathrm{g} \mathrm{ml}^{-1}$ ampicillin and $50 \mu \mathrm{g} \mathrm{ml}^{-1}$ chloramphenicol. Overnight cultures were transferred to $250 \mathrm{ml}$ of the same medium and maintained at $37^{\circ} \mathrm{C}$ until an $\mathrm{OD}_{600}$ of 0.8 was reached. IPTG was added to a final concentration of $1 \mathrm{mM}$ and different culture conditions were tested, two temperatures $\left(30\right.$ and $\left.37^{\circ} \mathrm{C}\right)$ and two induction periods $(5$ and $18 \mathrm{~h})$. After induction, cells were harvested by centrifugation 
$\left(3000 \times g, 15 \mathrm{~min}, 4^{\circ} \mathrm{C}\right)$ and the pellet was washed once with $50 \mathrm{mM} \mathrm{NaH}_{2} \mathrm{PO}_{4}, \mathrm{pH}$ 8.0. Cells were resuspended in Binding buffer $\left(50 \mathrm{mM} \mathrm{NaH}_{2} \mathrm{PO}_{4}, 300 \mathrm{mM} \mathrm{NaCl}, 10 \mathrm{mM}\right.$ imidazole, $\mathrm{pH}$ 8.0) and PMSF (40 $\mu \mathrm{g} \mathrm{ml}^{-1}$ final concentration) and disrupted by gentle sonication ( 7 cycles, $20 \mathrm{~s}$ ) on ice. Cell debris were separated from supernatant by centrifugation $\left(10000 \times g, 20 \mathrm{~min}, 4^{\circ} \mathrm{C}\right)$ in order to obtain the crude extract. The crude extract containing the recombinant lipase was loaded on a HiTrap column (GE Healthcare) previously equilibrated with Binding buffer and connected to an ÄKTA HPLC system (GE Healthcare). Recombinant lipase was eluted with an imidazole gradient ranging from 60 to $500 \mathrm{mM}$ and fractions of $1 \mathrm{ml}$ were collected. Purified lipase was submitted to dialysis (twice) for $24 \mathrm{~h}$ against 11 of $50 \mathrm{mM} \mathrm{NaH} \mathrm{PO}_{4}$ buffer, $300 \mathrm{mM}$ $\mathrm{NaCl}, \mathrm{pH}$ 8.0. Purity and apparent molecular mass were determined by SDS polyacrylamide gel electrophoresis. SDS-PAGE was carried out in gels containing $10 \%(\mathrm{w} / \mathrm{v})$ polyacrylamide according to standard protocols using BioRad Mini-PROTEAN ${ }^{\circledR}$ system. SDS-PAGE gels were stained with Coomassie Brilliant Blue R-250 and destained with methanol/acetic acid/water (5:1:4 v/v/v). Protein concentration was determined using a Bio-Rad protein assay kit with BSA as standard. Additional experiments of peptide mass fingerprinting by LC/MS of the tryptic digested lipase were performed using UFLC Prominence (Shimadzu Co. Japan) coupled to an HCT Ultra ETD II (Bruker Daltonics, Bremen, Germany) ion trap mass spectrometer.

Determination of Quaternary Structure

of the Recombinant Lipase by Gel Filtration

The quaternary structure of recombinant lipase in solution was estimated in triplicate by gel filtration on a Superdex 200 Prep Grade (GE Healthcare) connected to an ÄKTA HPLC System (GE Healthcare). Column was equilibrated with $\mathrm{NaH}_{2} \mathrm{PO}_{4} 50 \mathrm{mM}$ buffer, pH 8.0, containing $300 \mathrm{mM}$ $\mathrm{NaCl}$ and calibrated with: BSA, $66 \mathrm{kDa}$; carbonic anhydrase, $29 \mathrm{kDa}$; cytochrome C, $12.4 \mathrm{kDa}$; aprotinin, $6.5 \mathrm{kDa}$. Protein was eluted with the same buffer.

\section{Triglyceride Hydrolysis}

The ability to hydrolyze triglycerides was tested in a plate assay. LB medium was supplemented with $2 \%$ agar and $2.5 \%$ of olive oil and autoclaved. After sterilization, rhodamine $\mathrm{B}$ was added to a final concentration of $0.1 \mathrm{mg} \mathrm{ml}^{-1}$ and thoroughly blended before pouring into petri dishes. Then, $100 \mu \mathrm{l}$ of crude extracts from expression tests were applied on plate and incubated at $37^{\circ} \mathrm{C}$ for $24 \mathrm{~h}$. Triglyceride hydrolysis was identified by fluorescence under UV light at $350 \mathrm{~nm}$.
Lipase Activity Measurement

Enzymatic activities were determined according to Maia et al. [24] using $p$-nitrophenyl butyrate $\left(\mathrm{pNPC}_{4}\right)$ as substrate. Production of $p$-nitrophenol was continuously monitored at $410 \mathrm{~nm}$ (Microplate spectrophotometer TECAN Infinite Series M200) for $60 \mathrm{~min}$ in a final volume of $300 \mu$ l. In order to carry out the reaction, a stock solution of $8 \mathrm{mM}$ of $\mathrm{pNPC}_{4}$ was prepared in isopropanol and mixed with $50 \mathrm{mM}$ Tris- $\mathrm{HCl}, \mathrm{pH} 8.0$, to a final concentration of $1 \mathrm{mM} \mathrm{pNPC}_{4}$. Then, $270 \mu \mathrm{l}$ of substrate solution was mixed with $30 \mu \mathrm{l}$ of enzyme solution. Molar absorptivity of $p$-nitrophenol was experimentally determined as $18015.43 \mathrm{M}^{-1} \mathrm{~cm}^{-1}$. One unit of lipase was defined as the amount of enzyme that released $1 \mathrm{nmol}$ of $p$-nitrophenol per minute.

\section{Effect of $\mathrm{pH}$ and Temperature on Lipase Activity}

Effect of $\mathrm{pH}$ was investigated by assaying lipase activity at different $\mathrm{pH}$ values $(7.0,8.0$, and 9.0). The buffers used for $\mathrm{pH}$ tests were PIPES (50 mM, pH 7.0), Tris- $\mathrm{HCl}(50 \mathrm{mM}$, $\mathrm{pH}$ 8.0), and CHES (50 mM, pH 9.0). Reactions were carried out by mixing the appropriate buffer with a stock solution of $8 \mathrm{mM} \mathrm{pNPC}_{4}$ in order to obtain a substrate final concentration of $1 \mathrm{mM}$. Reactions were initiated by adding $30 \mu \mathrm{l}$ of enzyme $(25 \mu \mathrm{g})$ solution to $270 \mu \mathrm{l}$ of substrate solution. In order to investigate temperature effect, these reactions were carried out at 25,37 , and $42^{\circ} \mathrm{C}$ in a Microplate spectrophotometer (TECAN Infinite Series M200) as described above. Molar absorptivity of $p$-nitrophenol was experimentally determined for each $\mathrm{pH}$ as 9554.33 $\mathrm{M}^{-1} \mathrm{~cm}^{-1}$ (pH 7.0), $18015.43 \mathrm{M}^{-1} \mathrm{~cm}^{-1}(\mathrm{pH}$ 8.0), and $18669.31 \mathrm{M}^{-1} \mathrm{~cm}^{-1}$ (pH 9.0).

\section{Substrate Specificity}

Substrate specificity was assessed using $p$-nitrophenyl esters $\quad\left(\mathrm{pNPC}_{2}, \quad \mathrm{pNPC}_{4}, \quad \mathrm{pNPC}_{10}, \quad \mathrm{pNPC}_{12}, \quad \mathrm{pNPC}_{14}\right.$, $\left.\mathrm{pNPC}_{16}, \mathrm{pNPC}_{18}\right)$ as substrates. A stock solution $(8 \mathrm{mM})$ of each $p$-nitrophenyl ester was prepared in isopropanol. Substrates were emulsified to a final concentration of $1 \mathrm{mM}$ in $50 \mathrm{mM}$ CHES buffer, $\mathrm{pH}$ 9.0, containing gum arabic, $1.1 \mathrm{mg} \mathrm{ml}^{-1}$ and Triton X-100, $4.4 \mathrm{mg} \mathrm{ml}^{-1}$ [25]. The reaction mixture consisted of $270 \mu \mathrm{l}$ of emulsified substrate and $30 \mu \mathrm{l}$ of enzyme solution $(25 \mu \mathrm{g})$. Reactions were carried out at $42^{\circ} \mathrm{C}$ in a Microplate spectrophotometer (TECAN Infinite Series M200) as described above.

\section{Kinetic Parameters}

Lipase activity was measured as a function of various concentrations $(0.1,0.2,0.3,0.4,0.5,1$, and $2 \mathrm{mM})$ of 
$\mathrm{pNPC}_{4}$. Michaelis-Menten kinetic parameters: affinity constant $\left(K_{\mathrm{m}}\right)$, maximal velocity $\left(V_{\max }\right)$, and the turnover number $\left(k_{\mathrm{cat}}\right)$ were calculated from the experimental data points using GraphPad Prism 5.01 software. Catalytic efficiency $\left(K_{\mathrm{m}} / k_{\text {cat }}\right)$ was also determined.

\section{Thermostability Assay}

The assay to test the thermostability of recombinant lipase was performed by incubating the enzyme solution at $95^{\circ} \mathrm{C}$ in a water bath. Aliquots were collected after 10 , 20 , and $30 \mathrm{~min}$ and activity measurements were carried out at $42^{\circ} \mathrm{C}, \mathrm{pH} 9.0$ using $p$-nitrophenyl butyrate as substrate.

\section{Spectroscopy}

Protein samples were concentrated to $11 \mu \mathrm{M}$ in $20 \mathrm{mM}$ $\mathrm{NaCl}, 20 \mathrm{mM} \mathrm{NaH} \mathrm{PO}_{4}, \mathrm{pH} 7.4$, and scanned at $20^{\circ} \mathrm{C}$ using a $5 \mathrm{~mm}$ path length cell. CD spectra were recorded on a Jasco J-815 spectrometer equipped with a Peltier temperature control unit. The spectrum represents the average of five scans over the range of 195 to $280 \mathrm{~nm}$ with a step size of $0.1 \mathrm{~nm}$, bandwidth $2 \mathrm{~nm}$, and scan speed of $50 \mathrm{~nm} \mathrm{~min}{ }^{-1}$. The appreciative $\alpha$-helix content of protein was evaluated using the equation provided by Woody [25]:

$\%$ alpha helix $=\frac{\left(-[\theta]_{222 \mathrm{~nm}}+3000\right)}{39000}$

\section{Results}

Genomic DNA extracted from S. xylosus strain isolated from naturally fermented sausages [23] was used as the PCR template and the fragment flanked by primers LIP1/ LIP2 was amplified in order to obtain the sequence corresponding to mature lipase. This fragment was then re-amplified with primers LIPET1/LIPET2 in order to insert the recognition site for $X h o \mathrm{I}$ restriction enzyme. The fragment corresponding to the mature region of S. xylosus lipase was then cloned into pGEM-T Easy vector and this last recombinant plasmid, named $p G E M \_l i p 2$, was propagated in E. coli $\mathrm{DH} 5 \alpha$ and used for sequencing. Sequence analysis revealed a nucleotide sequence of $1084 \mathrm{bp}$ with a homology of $99 \%$ when compared with lipase sequence AF208229. Deduced amino acid sequence, which corresponds to the mature protein, presented 361 amino acids, a theoretical molecular weight of $40.47 \mathrm{kDa}$ and following identities with other staphylococcal lipases: $80 \%$ for lipase from S. hominis SK119 (EEK11887.1), 78\% for lipase from S. warnery (AB189474.1), and 78\% for lipase from S. epidermidis (AAA19729).
Expression and Purification of Recombinant S. xylosus Lipase

In order to clone the fragment corresponding to the mature region of the lipase into the $\mathrm{pET}-14 \mathrm{~b}$ expression vector, the pGEM_lip2 plasmid was digested with XhoI/SalI enzymes and the resulting fragment was inserted in pET-14b expression vector. Fragment insertion was confirmed by EcoRI digestion and sequencing. The fragment was inserted downstream and in-frame with a coding sequence corresponding to the following amino acid residues: MGG SHHHHHHSSGLVPAGSHMLEQGQYKNQD, where Q24 corresponds to Q1 of the mature lipase. The predicted cleavage site of AF208229 is not present in the recombinant lipase. A coding sequence corresponding to two amino acids, Asp and Pro, were added at the $3^{\prime}$ end of the fragment as a cloning artifact. The resulting recombinant plasmid was named $p E T 14 b \_l i p$.

BL21 (DE3) pLysS E. coli strain was transformed with the expression plasmid $p E T 14 b \_l i p$ in order to express the recombinant lipase with a histidine tag. Different induction periods $(5$ and $18 \mathrm{~h})$ and temperatures $\left(30\right.$ and $\left.37^{\circ} \mathrm{C}\right)$ were tested for expression of recombinant lipase. It was observed that the best condition was $5 \mathrm{~h}$ of induction at $30^{\circ} \mathrm{C}$ after the addition of $1 \mathrm{mM}$ IPTG in the growth medium, confirmed by an extra band of approximately $42 \mathrm{kDa}$ in SDS-PAGE (Fig. 1). Recombinant lipase was then purified to homogeneity from cell lysates by metalaffinity chromatography in a HiTrap column connected to an ÄKTA system using an imidazole gradient ranging from 60 to $500 \mathrm{mM}$. Fusion protein bound to resin was eluted in a total volume of $4 \mathrm{ml}$ when a concentration of $150 \mathrm{mM}$ imidazole was achieved (Fig. 1). Once imidazole interferes on lipase activity measurement by spectrophotometry using $p$-nitrophenyl esters as substrates, it was removed by

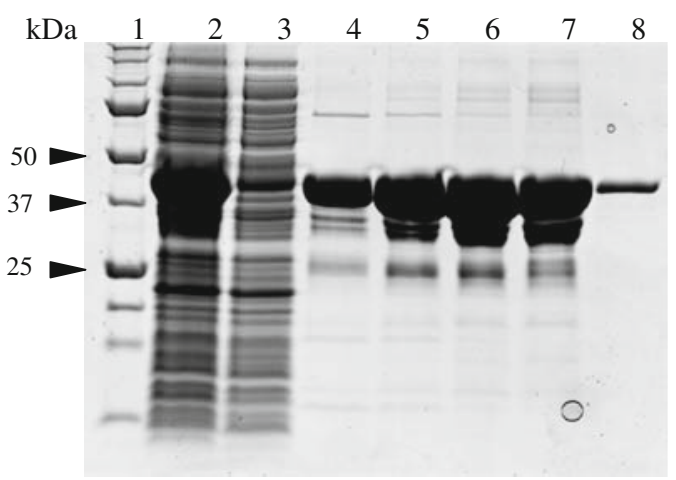

Fig. 1 SDS-PAGE of $S$. xylosus lipase purification in a HiTrap column. Lane 1 Molecular weight markers, lane 2 total soluble proteins of E. coli BL21(DE3) pLysS expressing S. xylosus lipase at $30^{\circ} \mathrm{C}$ after $5 \mathrm{~h}$ of induction, lane 3 proteins eluted from the column with $60 \mathrm{mM}$ imidazole, lanes 4-7 eluates containing recombinant lipase, lane 8 lipase after gel filtration. (15 $\mu \mathrm{l}$ were loaded per lane) 
dialysis against phosphate buffer as described in "Material and Methods".

Determination of His-Tagged Lipase Quaternary Structure

In a denaturing SDS-PAGE of the His-tagged lipase, a single band of approximately $42 \mathrm{kDa}$ is observed (Fig. 1). Electrophoretic mobility of His-tagged lipase was consistent with the theoretical molecular mass value $(42.9 \mathrm{kDa})$ predicted for the full-length recombinant protein. The identity of His-tagged lipase was confirmed by mass spectrometry (Fig. 2 and Table 1). Peptide mass fingerprinting of the tryptic digested recombinant lipase yielded at least 16 peptides which represented an overall sequence coverage of 145 residues out of 384 for the intact recombinant molecule in silico digested.

Monomeric state of native His-tagged lipase was determined by comparing its elution profile on a gel filtration column with that of protein size markers (Fig. 3). The recombinant lipase was eluted at $84.16 \mathrm{ml}$, between the elution volume of carbonic anhydrase (mw $29 \mathrm{kDa}$ ) and BSA (mw $66 \mathrm{kDa}$ ). From the linear correlation between elution volume and $\log m w$, the native recombinant lipase can be considered a monomer of approximately $42.6 \mathrm{kDa}$.

\section{Lipase Activity}

Regarding hydrolysis of olive oil by plate assay using rhodamine B, it was observed that crude extracts of E.coli harboring recombinant lipase presented ability to cleave this substrate, confirmed by the presence of fluorescence where crude extracts were applied (supplementary data).

Specific activity of recombinant lipase was determined by monitoring the production of $p$-nitrophenol from hydrolysis of $p$-nitrophenyl butyrate $\left(\mathrm{pNPC}_{4}\right)$ at $410 \mathrm{~nm}$. Purified recombinant lipase presented a specific activity of $1.47 \mathrm{U} \mathrm{mg}^{-1}$ at $25^{\circ} \mathrm{C}, \mathrm{pH} 8.0$.

Effect of $\mathrm{pH}$ and Temperature on Lipase Activity

Three $\mathrm{pH}$ values $(7.0,8.0$, and 9.0) and three temperatures $\left(25,37\right.$, and $\left.42^{\circ} \mathrm{C}\right)$ were tested with $\mathrm{pNPC}_{4}$ as substrate in order to determine the $\mathrm{pH}$ and temperature dependence on
Table 1 Detection by LC/MS of peptides derived from recombinant S. xylosus lipase after tryptic digestion

\begin{tabular}{lcr}
\hline Peptide sequence & Position & Mass (Da) \\
\hline LNIR & $60-63$ & 515.33 \\
AVELYYYIK & $80-96$ & 1161.62 \\
GGTVDYGAAHAEK & $97-109$ & 1275.59 \\
YGHER & $110-114$ & 661.30 \\
TYEGVYK & $118-124$ & 859.42 \\
DWQPGK & $125-130$ & 730.35 \\
VHLVAHSMGGQTVR & $132-145$ & 1491.78 \\
QLEELLR & $146-152$ & 900.51 \\
NGNQEEIEYQK & $153-163$ & 1351.30 \\
QLAFDYAK & $208-215$ & 955.49 \\
VDFGFGQWGLK & $224-234$ & 1253.63 \\
VQNSGLWK & $248-255$ & 931.50 \\
TEDNGFYDLTR & $256-266$ & 1330.30 \\
NTSLNPNIVYK & $275-285$ & 1262.67 \\
EWR & $324-326$ & 490.24 \\
GVWQVTPIK & $355-363$ & 1027.59 \\
\hline
\end{tabular}

the activity of recombinant S. xylosus lipase (Fig. 4). The enzyme is active at $\mathrm{pH}$ ranging from 7.0 to 9.0 with an optimal activity at $\mathrm{pH} 9.0\left(4.83 \mathrm{U} \mathrm{mg}^{-1}\right)$, the activity being drastically reduced to $0.88 \mathrm{U} \mathrm{mg}^{-1}$ at $\mathrm{pH} 7.0$. Regarding the temperature dependence, $S$. xylosus lipase presented the highest activity at $42^{\circ} \mathrm{C}$ (Fig. 4). Moreover, the enzyme presented an important thermal stability. Recombinant enzyme was incubated at $95^{\circ} \mathrm{C}$ for 10,20 , and $30 \mathrm{~min}$. After the heat treatment, lipase activity was measured at $42^{\circ} \mathrm{C}$ and pH 9.0 using $p$-nitrophenyl butyrate as substrate and the enzyme retained $77 \%$ of the initial activity (Fig. 5).

\section{Substrate Specificity}

Substrate specificity was assessed by testing enzymatic activity against several $p$-nitrophenyl esters of different chain lengths ( $p$-nitrophenyl acetate, $p$-nitrophenyl butyrate, $p$-nitrophenyl decanoate, $p$-nitrophenyl laurate, $p$-nitrophenyl myristate, $p$-nitrophenyl palmitate, and $p$-nitrophenyl estearate) at $\mathrm{pH} 9.0$ and $42^{\circ} \mathrm{C}$ (Fig. 6). S. xylosus recombinant lipase presented the highest activity for $p$-nitrophenyl acetate $\left(10.15 \mathrm{U} \mathrm{mg}^{-1}\right)$, followed by
Fig. 2 Amino acid sequence of recombinant $S$. xylosus lipase. Peptides identified by LC/MS are showed underlined and gray boxes. Mass spectrometry was performed in a UFLC Prominence coupled to an HCT Ultra ETD II ion trap
MGGSHHHHHHSSGLVPAGSHMLEQGQYKNQDPIILVHGFNGFTDDINPAVLAH YWGGDKLNIRQDLESNGYETYEASVGALSSNYDRAVELYYYIKGGTVDYGAA HAEKYGHERYGKTYEGVYKDWQPGKKVHLVAHSMGGQTVRQLEELLRNGN QEEIEYQKEHGGEISPLFQGNNDNMVNSITTIGTPHNGTHAADALGNEAIVRQL AFDYAKFKGNKNSKVDFGFGQWGLKQREGETYAQYVQRVQNSGLWKTEDNG FYDLTREGAAKLNKNTSLNPNIVYKTYTGESTRPTLFGNQKSDVNLFLPFTVTG NVIGKAAEKEWRENDGLVSTISSQHPFNQAFIEATDEVKKGVWQVTPIKHGWD HVDFVGQDSTDSNHPTE 


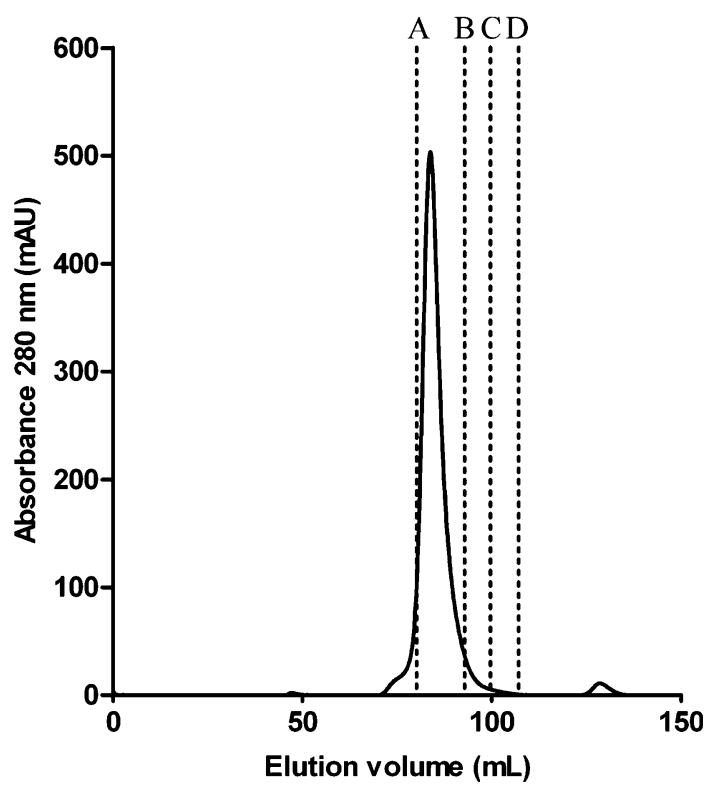

Fig. 3 Gel filtration chromatography of $S$. xylosus lipase on a Superdex 200 Prep Grade column. Dashed vertical lines $(A-D)$ represent molecular markers used for calibrating the column. (A) BSA $(66 \mathrm{kDa}, 80.21 \mathrm{ml}),(B)$ carbonic anhydrase $(29 \mathrm{kDa}, 92.91 \mathrm{ml}),(C)$ cytochrome C $(12.4 \mathrm{kDa}, 99.68 \mathrm{ml})$, and $(D)$ aprotinin $(6.5 \mathrm{kDa}$, $107.09 \mathrm{ml})$. Elution volume of His-tagged S. xylosus lipase was of $84.19 \mathrm{ml}$

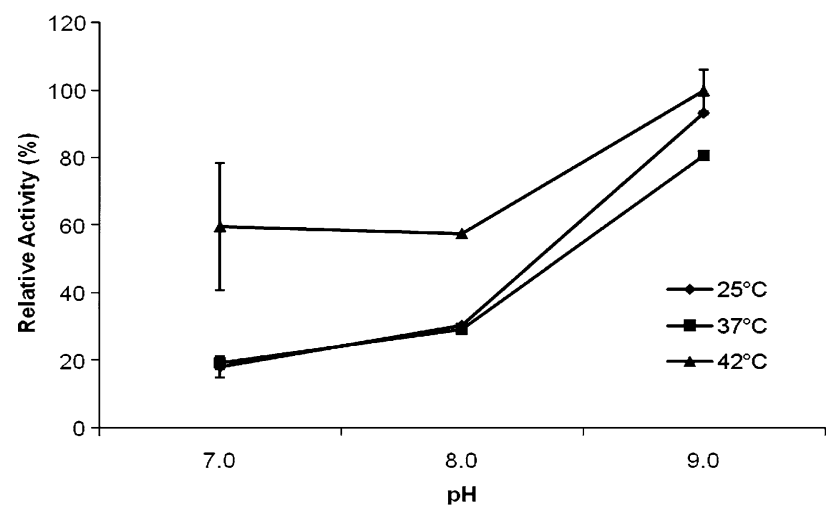

Fig. 4 Effect of $\mathrm{pH}$ and temperature on the activity of recombinant S. xylosus lipase. Activity assay was carried out with $1 \mathrm{mM}$ $p$-nitrophenyl butyrate as substrate in $50 \mathrm{mM}$ of appropriate buffer at different $\mathrm{pH}$ values and temperatures, $25^{\circ} \mathrm{C}$ (circles), $37^{\circ} \mathrm{C}$ (squares), and $42^{\circ} \mathrm{C}$ (triangles). Lipase activity was measured in a microplate spectrophotometer. Results are expressed as percentage of the lipase activity measured at $\mathrm{pH} 9$ and $42^{\circ} \mathrm{C}$

$p$-nitrophenyl butyrate $\left(4.83 \mathrm{U} \mathrm{mg}^{-1}\right)$. The lowest activity resulted when $p$-nitrophenyl estearate was assayed as substrate $\left(0.313 \mathrm{U} \mathrm{mg}^{-1}\right)$.

\section{Kinetic Parameters}

Kinetic parameters for recombinant $S$. xylosus lipase were determined by measuring rates of hydrolysis of different

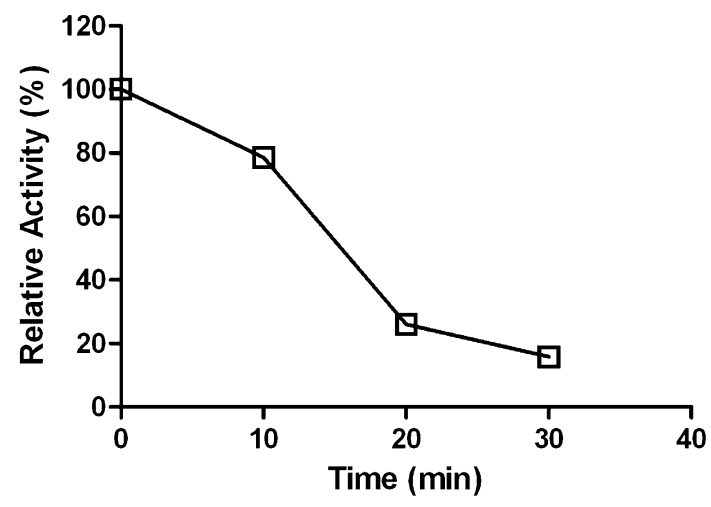

Fig. 5 Thermostability of recombinant S. xylosus at $95^{\circ} \mathrm{C}$. Histagged enzyme was incubated at $95^{\circ} \mathrm{C}$ during 10,20 , and $30 \mathrm{~min}$. After the heat treatment, lipase activity was measured at $42^{\circ} \mathrm{C}$ and $\mathrm{pH}$ 9.0 using $p$-nitrophenyl butyrate as substrate. Results are expressed as percentage of the lipase activity

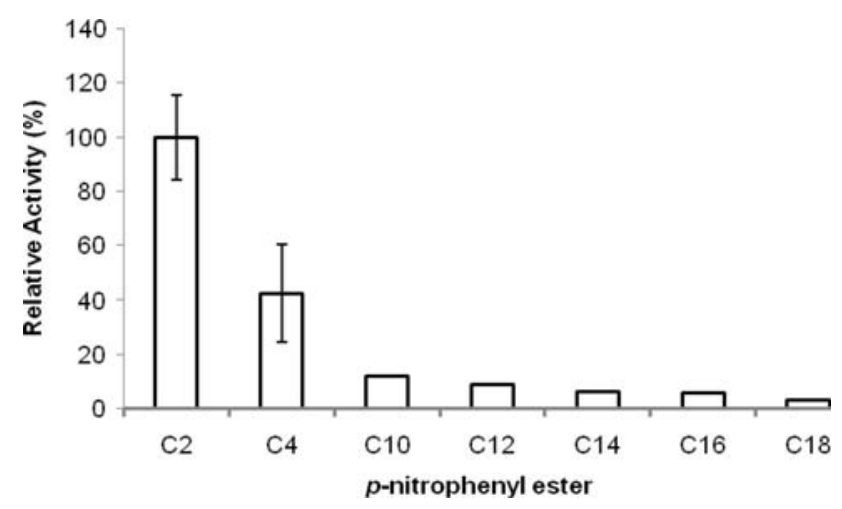

Fig. 6 Relative activity of recombinant $S$. xylosus on $p$-nitrophenyl esters with different chain length at $\mathrm{pH} 9$ and $42^{\circ} \mathrm{C}$. Hydrolysis was measured for $p$-nitrophenyl acetate $(\mathrm{C} 2), p$-nitrophenyl butyrate $(\mathrm{C} 4)$, $p$-nitrophenyl decanoate (C10), $p$-nitrophenyl laurate (C12), $p$-nitrophenyl myristate (C14), p-nitrophenyl palmitate (C16), and $p$-nitrophenyl estearate $(\mathrm{C} 18)$. Results are expressed as percentage of the lipase activity assayed with $p$-nitrophenyl acetate as substrate

concentrations of $\mathrm{pNPC}_{4}$. Michaelis-Menten data was plotted (Fig. 7) and maximal velocity $\left(V_{\max }\right)$, affinity constant $\left(K_{m}\right)$, turnover number $\left(k_{\text {cat }}\right)$, and catalytic efficiency $\left(K_{m} / k_{\text {cat }}\right)$ were determined (Table 2$)$.

\section{Spectroscopy}

S. xylosus recombinant lipase has a typical $\alpha$-helix profile, the far-UV CD spectrum displayed minimal peaks at $208 \mathrm{~nm}$ and $222 \mathrm{~nm}$ (Fig. 8). Analysis of the spectrum [26] suggests that the amount of $\alpha$-helical secondary structures represent a total of $49.65 \%$, which is quite expected for a member of the $\alpha / \beta$-hydrolases family, as previously described [5, 27]. 


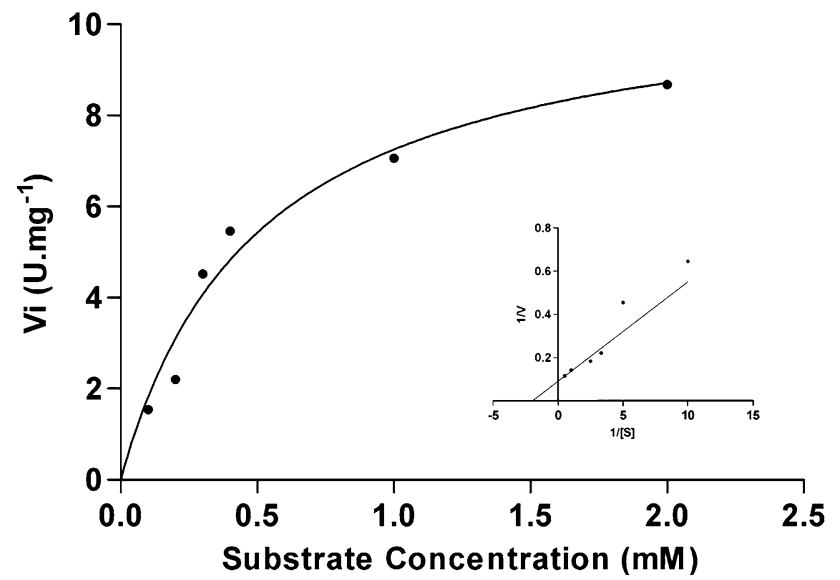

Fig. 7 Michaelis-Menten plot of recombinant lipase from S. xylosus determined by measuring release of $p$-nitrophenyl from several $\mathrm{pNPC}_{4}$ concentrations. Inset graph shows the Lineweaver-Burk plot of the transformed data. Assays were performed in $50 \mathrm{mM}$ CHES buffer $\mathrm{pH} 9.0$ at $42^{\circ} \mathrm{C}$

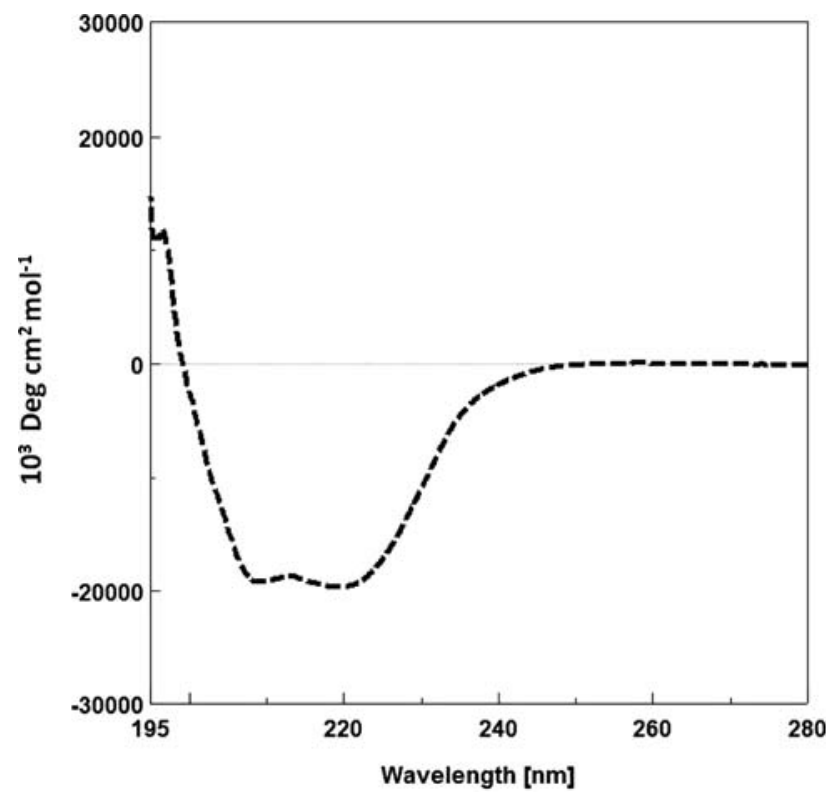

Fig. 8 Circular dichroism spectra of recombinant $S$. xylosus lipase at $20^{\circ} \mathrm{C}$. Minima at $208 \mathrm{~nm}$ and $222 \mathrm{~nm}$ indicate a typical $\alpha$-helix profile

Table 2 Kinetic parameters of recombinant S. xylosus lipase for $\mathrm{pNPC}_{4}$

\begin{tabular}{|c|c|c|c|c|}
\hline $\begin{array}{l}\text { Specific } \\
\text { activity (U/mg) }\end{array}$ & $\begin{array}{l}V_{\max } \\
\left(\mathrm{nmol} \min ^{-1} \mathrm{mg}^{-1}\right)\end{array}$ & $\begin{array}{l}K_{\mathrm{M}} \\
(\mathrm{mM})\end{array}$ & $\begin{array}{l}k_{\mathrm{cat}} \\
\left(\mathrm{s}^{-1}\right)\end{array}$ & $\begin{array}{l}k \mathrm{cat} / K_{\mathrm{M}} \\
\left(\mathrm{s}^{-1} \mathrm{mM}^{-1}\right)\end{array}$ \\
\hline 7.06 & 10.93 & 0.507 & 0.0078 & 0.0154 \\
\hline
\end{tabular}

\section{Discussion}

In the present work, the fragment corresponding to the mature region of lipase gene from Staphylococcus xylosus strain isolated from naturally fermented sausages was cloned, sequenced, and successfully expressed in E. coli BL21 (DE3) pLysS. It presented a homology of 99\% when compared to the lipase sequence AF208229 cloned from $S$. xylosus DSM 20266 strain [6], this late enzyme was not previously characterized. Activity of lipases is dependent upon a charge substitution system involving an active SerAsp/Glu-His triad, called catalytic triad [28]. Besides, the active serine residue of catalytic triad is commonly found in the highly conserved motif Gly-X-Ser-X-Gly [28]. Mosbah et al. [22] cloned and expressed the lipase AF701336 from a S. xylosus strain isolated from oil industry waste that presents the complete consensus sequence Gly-X-Ser-X-Gly. Amino acid sequence of $S$. xylosus lipase AF208229 presents 53\% identity with the lipase AF701336 [22]. The purified recombinant lipase of S. xylosus strain isolated from fermented sausages is a monomer, as determined by size-exclusion chromatography. The lipase AF701336 from S. xylosus is also a monomeric protein [22]. Unlike other previously described staphylococcal lipases that presented properties of forming aggregates under native conditions [22], these two $S$. $x y$ losus lipases remain as monomeric proteins in solution.

Lipases are versatile enzymes that express activity of synthesis and hydrolysis besides presenting other esterase type of activities and exhibiting large substrate specificities [29]. Generally, staphylococcal lipases present their highest activities at alkaline $\mathrm{pH}$, with some exceptions such as SAL-1 from S. aureus and SEL-3 from S. epidermidis [6]. SAL-3 from $S$. aureus, recently characterized showed the highest activity at $\mathrm{pH} 9.5$ and $55^{\circ} \mathrm{C}$ [30]. Besides, $S$. $x y$ losus lipase AF701336 presented highest activity at $\mathrm{pH} 8.2$ and $45^{\circ} \mathrm{C}$ [22]. The recombinant $S$. xylosus lipase presented in this work seems to have similar preferences for high $\mathrm{pH}$ and high temperature for maximum activity, $\mathrm{pH}$ 9.0, and $42^{\circ} \mathrm{C}$ being the preferred conditions. Besides, it presented quite impressive heat-tolerance when exposed to high temperatures. After 10, 20, and $30 \mathrm{~min}$ at $95^{\circ} \mathrm{C}$, the enzyme retained 77,24 , and $14 \%$ from the initial activity, respectively. Information about the thermostability of staphylococcal lipases is scarce at present, the only examples being lipase from of $S$. xylosus that maintains $50 \%$ of its activity after $15 \mathrm{~min}$ at $60^{\circ} \mathrm{C}$ [22] and lipase from $S$. saprophyticus, which maintains $80 \%$ of its activity after $15 \mathrm{~min}$ at $70^{\circ} \mathrm{C}$ and $30 \%$ after $15 \mathrm{~min}$ of boiling [31]. Also, a lipase from $S$. simulans is inactivated after a few minutes at $60^{\circ} \mathrm{C}$ [32]. In fact, thermostable enzymes have found several applications due to its inherent stability [33, 34] although applications for staphylococcal thermostable lipases have not been reported. An important advantage of conducting biotechnological processes at elevated temperatures is to reduce the risk of contamination by common mesophiles [35]. Besides, elevated temperatures allow also higher reaction rates due to a decrease in viscosity and an 
increase in diffusion coefficient of substrates and higher process yield due to increased solubility of substrates and products [34]. Thus, ability of lipases to remain stable at high temperatures is an important and valuable feature for biotechnological applications.

Some staphylococcal lipases, such as SEL3 from S. epidermidis, SHaL from $S$. haemolyticus, SAL1 from $S$. aureus, SWL2 from $S$. warneri preferably hydrolyze water-soluble short-chain substrates $[6,31,36]$, while SHyL from S. hyicus and SXL lipase (AF701336) from S. xylosus [22] present no specificity for chain length when hydrolyzing triacylglycerols. Lipase from S. saprophyticus presented the same profile of the recombinant enzyme purified in the present work for chain length specificity, with a preference for $\mathrm{pNPC}_{2}$ followed by $\mathrm{pNPC}_{4}$ [31] besides presenting different optimal temperature $\left(30^{\circ} \mathrm{C}\right)$ and $\mathrm{pH}(6.0)$.

Regarding the kinetic parameters, the low value of $K_{\mathrm{m}}$ $(0.5 \mathrm{mM})$ observed for recombinant lipase of $S$. xylosus shows that this enzyme presents high affinity for the substrate with four carbons in the lateral chain. A lipase from S. saprophytics presented a $K_{\mathrm{m}}$ value of $1.47 \mathrm{mM}$ for the same substrate [31] and a recombinant lipase from S. epidermidis presented $0.9 \mathrm{mM}$ [37]. The $k_{\text {cat }}$ value presented by the recombinant lipase from S. xylosus $\left(0.0078 \mathrm{~s}^{-1}\right)$ was lower than recombinant lipase of $S$. epidermidis $\left(25.1 \mathrm{~s}^{-1}\right)$ [37] as well as catalytic efficiency $\left(0.0154\right.$ and $28.2 \mathrm{~s}^{-1}$ $\mathrm{mM}^{-1}$, respectively).

The $\alpha / \beta$-hydrolase fold is characterized by five to eight strands connected by $\alpha$-helices to form an $\alpha / \beta / \alpha$ sandwich. In most of the family members the $\beta$-strands are parallel [38]. The S. xylosus recombinant lipase from this work presents a $\sim 47 \%$ alpha helix content, compatible with the secondary structure content of the 3D structure determined for $S$. hyicus lipase [5], which presents 3 parallel $\beta$-strands and $12 \alpha$-helix. The members of this superfamily diverged from a common ancestor into a number of hydrolytic enzymes with a wide range of substrate specificities, together with other proteins with no recognized catalytic activity [38]. Comparing with $S$. hyicus lipase structure, the catalytic triad of S. xylosus recombinant lipase is present in loops, one of them, the nucleophilic elbow, is the most conserved feature of the fold, which occurs in the majority of this family members [38].

Esters of short chain fatty acids are known as flavor compounds being widely used in food, beverage, cosmetic, and pharmaceutical industries [39]. There is an increasing preference for "natural" products rather than for chemically synthesized flavors [40] mainly due to the fact that chemical catalysis uses polluting liquid acids as catalysts [41] and leads to dark-colored products and undesired byproducts [42]. Besides, flavor esters produced by enzymatic synthesis may be labeled as "natural" products. Several reports about the production of such interesting compounds by lipases are available [39-41, 43, 44], including S. warneri, S. xylosus [45], and S. epidermidis [42] lipases. We thus propose the recombinant lipase from $S$. xylosus presented in this work to be useful in producing esters of short-chain fatty acids.

\section{Conclusion}

A gene coding for $S$. xylosus lipase was successfully cloned and expressed. The amplified sequence obtained in this work presented a 99\% similarity with the lipase (AF208229) from S. xylosus DSM 20266 strain. This is the first report to show the S. xylosus lipase (AF208229) purification to homogeneity, biochemical, and biophysical characterization. The purified histidine-tagged lipase presented high specific activity at $\mathrm{pH} 9.0$ and $42^{\circ} \mathrm{C}$ for $p$-nitrophenyl acetate and $p$-nitrophenyl butyrate. Also, the recombinant lipase presented an impressive heat-tolerance when submitted to $95^{\circ} \mathrm{C}$ for $10 \mathrm{~min}$. Further structural and biochemical characterization is necessary to achieve a full understanding of this enzyme and its reaction mechanism, and this will be the subject of future communications.

Acknowledgments The present work was financially supported by CNPq processes 476285/2007-0 and 552508/2007-1, and Rede Proteoma de Santa Catarina (FAPESC/FINEP/MCT). MRP was supported by a fellowship from Universidade do Contestado (UnC) and FCAB was recipient of a fellowship from CAPES, Ministry of Education, Brazil. We also express our gratitude to Centro de Biotecnologia, Universidade Federal do Rio Grande do Sul for sequence data.

\section{References}

1. Secundo, F., Carrea, G., Tarabiono, C., Gatti-Lafranconi, P., Brocca, S., Lotti, M., et al. (2006). The lid is a structural and functional determinant of lipase activity and selectivity. Journal of Molecular Catalysis B Enzymatic, 39, 166-170.

2. Hasan, F., Shah, A. A., \& Hameed, A. (2006). Industrial applications of microbial lipases. Enzyme and Microbial Technology, 39, 235-251.

3. Roustan, J. L., Chu, A. R., Moulin, G., \& Bigey, F. (2005). A novel lipase/acyltransferase from the yeast Candida albicans: Expression and characterization of the recombinant enzyme. Applied Microbiology and Biotechnology, 68, 203-212.

4. Tyndall, J. D. A., Sinchaikul, S., Fothergill-Gilmore, L. A., Taylor, P., \& Walkinshaw, M. D. (2002). Crystal structure of a thermostable lipase from Bacillus stearothermophilus P1. Journal of Molecular Biology, 323, 859-869.

5. Tiesinga, J. J. W., van Pouderoyen, G., Nardini, M., Ransac, S., \& Dijkstra, B. W. (2007). Structural basis of phospholipase activity of Staphylococcus hyicus lipase. Journal of Molecular Biology, 371, 447-456.

6. Rosenstein, R., \& Götz, F. (2000). Staphylococcal lipases: Biochemical and molecular characterization. Biochimie, 82, 10051014.

7. Gupta, R., Gupta, N., \& Rathi, P. (2004). Bacterial lipases: An overview of production, purification and biochemical properties. Applied Microbiology and Biotechnology, 64, 763-781. 
8. Lumor, S. E., \& Akoh, C. C. (2008). Esterification and hydrolytic activities of Candida rugosa lipase isoform 1 (LIP1) immobilized on celite 545, duolite A7, and sephadex G-25. Journal of Agriculture and Food Chemistry, 56, 10396-10398.

9. Chakraborty, K., \& Raj, R. P. (2008). An extra-cellular alkaline metallolipase from Bacillus licheniformis MTCC 6824: Purification and biochemical characterization. Food Chemistry, 109, 727-736.

10. Ha, S. H., Lan, M. N., Lee, S. H., Hwang, S. M., \& Koo, Y. M. (2007). Lipase catalyzed biodiesel production from soybean oil in ionic liquids. Enyzme and Microbial Technology, 41, 480-483.

11. Yao, H., Yu, S., Zhang, L., Zuo, K., Ling, H., Zhang, F., et al. (2008). Isolation of a novel lipase gene from Serratia liquefaciens S33 DB-1, functional expression in Pichia pastoris and its properties. Molecular Biotechnology, 38, 99-107.

12. Quintana-Castro, R., Díaz, P., Gerardo Valerio-Alfaro, G., Hugo, S., García, H. S., \& Rosamaría Oliart-Ros, R. (2009). Gene cloning, expression, and characterization of the Geobacillus thermoleovorans CCR11 thermoalkaliphilic lipase. Molecular Biotechnology, 42, 75-83.

13. Jiang, Z., Zheng, Y., Luo, Y., Wang, G., Wang, W., Ma, Y., et al. (2005). Cloning and expression of a novel lipase gene from Pseudomonas fluorescens B52. Molecular Biotechnology, 31, 95-101.

14. Lui, B., Qian, X., Wu, Q., \& Lin, X. (2008). Two lipase-catalyzed sequential synthesis of drug derivatives in organic media. Enyzme and Microbial Technology, 43, 375-380.

15. Morot-Bizot, S., Talon, R., \& Leroy-Setrin, S. (2003). Development of specific PCR primers for a rapid and accurate identification of Staphylococcus xylosus, a species used in food fermentation. Journal of Microbiol Methods, 55, 279-286.

16. Iacumin, L., Cocolin, L., Cantoni, C., \& Comi, G. (2007). Preliminary analysis of the lipase gene (gehM) expression of Staphylococcus xylosus in vitro and during fermentation of naturally fermented sausages (in situ). Journal of Food Protection, 70, 2665-2669.

17. Rantsiou, K., Iacumin, L., Cantoni, C., Comi, G., \& Cocolin, L. (2005). Ecology and characterization by molecular methods of Staphylococcus species isolated from fresh sausages. International Journal of Food Microbiology, 97, 277-284.

18. Simonová, M., Strompfová, V., Marcináková, M., Lauková, A., Vesterlund, S., Latorre-Moratalla, M., et al. (2006). Characterization of Staphylococcus xylosus and Staphylococcus carnosus isolated from Slovak meat products. Meat Science, 73, 559-564.

19. Kozacinski, L., Drosinos, E., Caklovica, F., Cocolin, F., Gasparik-Reichardt, J., \& Veskovic, S. (2008). Investigation of microbial association of traditionally fermented sausages. Food Technology and Biotechnology, 46, 93-108.

20. Talon, R., Walter, D., Chariter, S., Barrière, C., \& Montel, M. C. (1999). Effect of nitrate and incubation conditions on the production of catalase and nitrate reductase by staphylococci. International Journal of Food Microbiology, 52, 47-56.

21. Iacumin, L., Comi, G., Cantoni, C., \& Cocolin, L. (2006). Molecular and technological characterization of Staphylococcus xylosus isolated from naturally fermented Italian sausages by RAPD, Rep-PCR and Sau-PCR analysis. Meat Science, 74(2), 281-288.

22. Mosbah, H., Sayari, A., Mejdoub, H., Dhouib, H., \& Gargouri, Y. (2005). Biochemical and molecular characterization of Staphylococcus xylosus lipase. Biochimica et Biophysica Acta, 1723, 282-291.

23. Fiorentini, A. M., Sawitzki, M. C., Bertol, T. M., Brod, F. C. A., Pelisser, M. R., Arisi, A. C. M., et al. (2009). Phenotypic and molecular characterization of Staphylococcus xylosus: Technological potential for use in fermented sausage. Brazilian Archives of Biology and Technology, 52, 737-746.
24. Maia, M. D. D., Heasley, A., Camargo de Morais, M. M., Melo, E. H. M., Morais, M. A., Jr, Ledingham, W. M., et al. (2001). Effect of culture conditions on lipase production by Fusarium solani in batch fermentation. Bioresource Technology, 76, 23-27.

25. Woody, R. W. (1995). Circular dichroism. Methods in Enzymology, 246, 34-71.

26. Kelly, S. M., \& Price, N. C. (2000). The use of circular dichroism in the investigation of protein structure and function. Current Protein and Peptide Science, 1(4), 349-384.

27. Ollis, D. L., Cheah, E., Cygler, M., Dijkstra, B., Frolow, F., Franken, S. M., et al. (1992). The alpha/beta hydrolase fold. Protein Engineering, 5, 197-211.

28. Jaeger, K. E., Dijkstra, B. W., \& Reetz, M. T. (1999). Bacterial biocatalysts: Molecular biology, three-dimensional structures and biotechnological applications of lipases. Annual Review of Microbiology, 53, 315-335.

29. Svendsen, A. (2000). Lipase protein engineering. Biochimica et Biophysica Acta, 1543, 223-238.

30. Horchani, H., Mosbah, H., Salem, N. B., Gargouri, Y., \& Sayari, A. (2009). Biochemical and molecular characterization of a thermoactive, alkaline and detergent-stable lipase from a newly isolated Staphylococcus aureus strain. Journal of Molecular Catalysis B Enzymatic, 56(4), 237-245.

31. Sakinç, T., Kleine, B., \& Gatermann, S. G. (2007). Biochemical characterization of the surface-associated lipase of Staphylococcus saprophyticus. FEMS Microbiology Letters, 274, 335-341.

32. Sayari, A., Agrebi, N., Jaoua, S., \& Gargouri, Y. (2001). Biochemical and molecular characterization of Staphylococcus simulans lipase. Biochimie, 83, 863-871.

33. Demirijan, D., Moris-Varas, F., \& Cassidy, C. (2001). Enzymes from extremophiles. Current Opinion in Chemical Biology, 5, $144-151$.

34. Haki, G. D., \& Rakshit, S. K. (2003). Developments in industrially important thermostable enzymes: A review. Bioresource Technology, 89, 17-34.

35. Palma-Fernandez, E. R., Gomes, E., \& Silva, R. (2002). Purification and characterization of two b-glucosidases from the thermophilic fungus Thermoascus aurantiacus. Folia Microbiologica, 47, 685-690.

36. Van Kampen, M. D., Rosenstein, R., Götz, F., \& Egmond, M. R. (2001). Cloning, purification and characterization of Staphylococcus warneri lipase 2. Biochimica et Biophysica Acta, 1554, 229-241.

37. Chang, R. C., Chou, S. J., \& Shaw, J. F. (2000). Site-directed mutagenesis of a highly active Staphylococcus epidermidis lipase fragment identifies residues essential for catalysis. Journal of the American Oil Chemists' Society, 77, 1021-1025.

38. Hotelier, T., Renault, L., Cousin, X., Negre, V., Marchot, P., \& Chatonnet, A. (2004). ESTHER, the database of the $\alpha / \beta$-hydrolase fold superfamily of proteins. Nucleic Acid Research, 32, 145-147.

39. Macedo, G. A., Lozano, M. M. S., \& Pastore, G. M. (2003). Enzymatic synthesis of short chain citronellyl esters by a new lipase from Rhizopus sp. Electronic Journal of Biotechnology, 6, 72-75.

40. Larios, A., García, H. S., Oliart, R. S., \& Valerio-Alfaro, G. (2004). Synthesis of flavor and fragrance esters using Candida antartica lipase. Applied Microbiology and Biotechnology, 65, 373-376.

41. Salah, R. B., Ghamghui, H., Miled, N., Mejdoub, H., \& Gargouri, Y. (2007). Production of butyl acetate ester by lipase from novel strain of Rhizopus oryzae. Journal of Bioscience and Bioengineering, 103(4), 368-372.

42. Chang, R. C., Chou, S. J., \& Shaw, J. F. (2001). Synthesis of fatty esters by recombinant Staphylococcus epidermidis lipases in aqueous environment. Journal of Agriculture and Food Chemistry, 49, 2619-2622. 
43. Chen, J. P. (1996). Production of ethyl butyrate using gelentrapped Candida cylindracea lipase. Journal of Fermentation and Bioengineering, 82(4), 404-407.

44. Liu, S. Q., Holland, R., \& Crow, V. (2003). Synthesis of ethyl butanoate by a commercial lipase in aqueous media under conditions relevant to cheese ripening. Journal of Dairy Research, 70, 359-363.

45. Talon, R., Montel, M. C., \& Berdague, J. L. (1996). Production of flavor esters by lipases of Staphylococcus warneri and Staphylococcus xylosus. Enyzme and Microbial Technology, 19, 620-622. 